\title{
MATHEMATICAL EXPRESSION OF RELATIONSHIP BETWEEN AUDITORY BRAINSTEM TRANSMISSION TIME AND AGE
}

Mario Fabiani

Haim Sohmer

Charles Tait

Oreste Bordieri

It has been shown that there is a relationship between the absolute latencies of auditory brainstem response (ABR) waves and the age of the subject (Lieberman et al. 1973, Hecox and Galambos 1974, Salamy et al. 1975, Salamy and McKean 1976). However, the absolute latency of an ABR wave may vary as a function of stimulus intensity (Pratt and Sohmer 1976), stimulus repetition rate (Hyde et al. 1976, Pratt and Sohmer 1976) and stimulus frequency (Brama and Sohmer 1977). In addition, a conductive hearing-loss also gives rise to increased absolute response latencies (Sohmer and Cohen 1976).

For these reasons the measurement of absolute ABR wave latency for neurological diagnosis can be misleading, and several workers have suggested the alternative of measuring the time interval between certain waves (Salamy et al. 1975, Starr 1977, Sohmer and Student 1978, Fabiani et al. 1979). Since the end-point (wave V or $4 b)$ of the time interval suggested by several of these workers may be variable (Chiappa and Gladstone 1978), we have suggested previously that the measurement should be of the time interval between the auditory-nerve response (wave I) and the vertex negative wave following wave $v$ (or $4 b$ ). We have found this end-point to be considerably more stable and invariant in many conditions than the vertex positive wave (Fabiani et al. 1979). Since the transmission time-interval is an expression of the progress of excitation from the auditory nerve to the inferior colliculus of the brainstem, this interval has been referred to as brainstem transmission time (BTT) (Fig. 1). It is called transmission rather than conduction time since, in the otological-audiological context, conduction refers to the transfer of vibrations from the tympanic membrane by the middle-ear ossicles to the inner ear. It has been shown that BTT is independent of stimulus intensity and frequency, is invariant at stimulus repetition rates below $20 / \mathrm{sec}$, and is constant even in the presence of a conductive hearing-loss (Fabiani et al. 1979).

The purpose of this paper is to describe in quantitative terms the dependence of BTT on age, and to evaluate the rate at which BTT decreases with age from birth to apparently complete maturation of the brainstem auditory pathways.

\section{Method}

Recordings were made of auditory-nerve and brainstem responses of neonates, infants, young children and young adults (71 subjects, totalling 133 ears). Anamnestic data in all cases showed no riskfactor for auditory or brain dysfunction. 


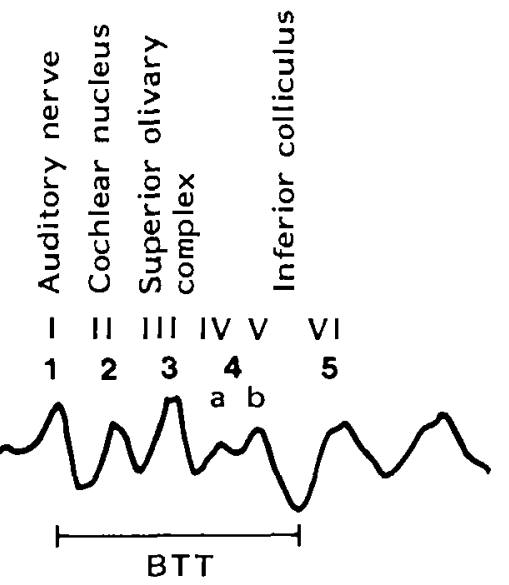

Fig. 1. BTT time-interval between $W_{1}(=I)$ and downward wave following $W_{b 4}(=V)$. BTT of waves $4 a$ and $4 b$ ( $I V$ and $V$ ) were not measured since they were variable and often fused.

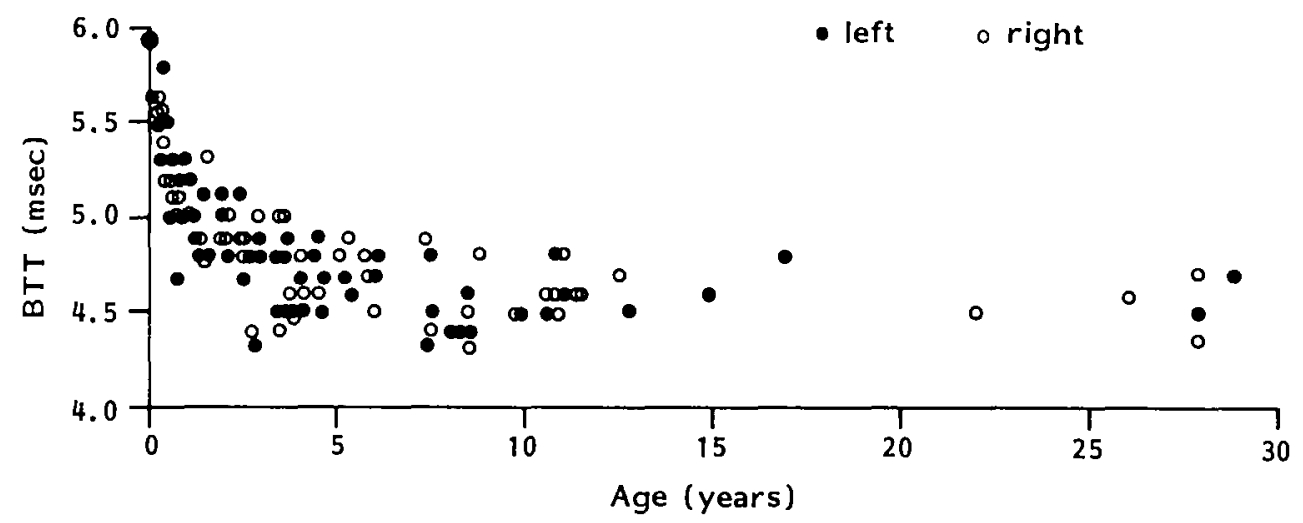

Fig. 2. Scalter-plot of values of BTT as function of age. Large point at top left represents age ' 0 ' and is average value obtained for 13 neonates: values for both ears (22) have been averaged rogether.

The neonates were tested during natural sleep, and recordings for the infants and many of the younger children were made in the postoperative recovery room during sleep following minor surgical procedures (e.g. reduction of umbilical hernia, opening of congenital phymosis), unrelated to the head or neck. It has been demonstrated that the anaesthetic agents used for these operations do not affect auditory brainstem responses in children (Duncan et al. 1979). Recordings were not made from ears in which there was an obvious conductive hearing-loss.

Each ear was stimulated separately with $20 / \mathrm{sec}$ click stimuli, alternating in polarity, population. Responses were recorded as the potential difference between an earlobe electrode and a scalp vertex disc electrode. The recorded activity was bandpass filtered $(250$ to $5000 \mathrm{~Hz})$ in order to eliminate the slow ear-lobe negative wave, thus accentuating the sharper ear-lobe positive wave generated in the region of the inferior colliculus $\left(\mathrm{P}_{4}\right)$. The responses were amplified and signal averaged. The BTT was measured from oscillographic photographs of the average response trace to 1024 stimulus repetitions, using a millimetric meter with graduations of $0 \cdot 1 \mathrm{msec}$.

The 133 BTT values ( 65 for right and 68 for left ears) were plotted separately as a 
Fig. 3. Confidence band of function log $B T T=K+B T$ from birth to 100 months. Mean $\pm S D$ values from experimental data up to age eight years are also plotted.

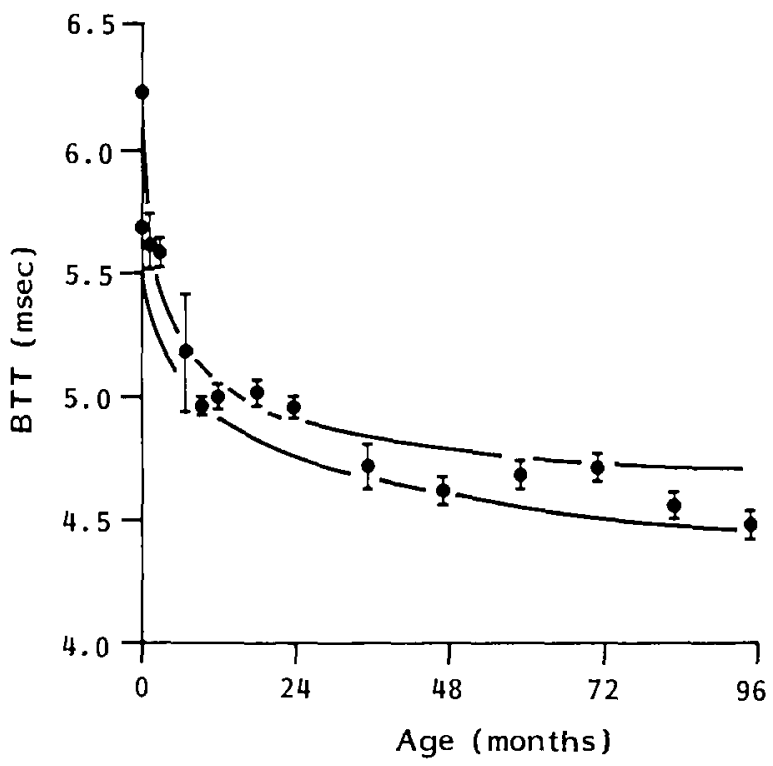

$K_{o}=1 \cdot 656 ; B_{0}=-0.0013$. In analysing the correlation between BTT and T, the sample coefficient of determination $\mathrm{r}^{2}$ resulted in 0.492 and the coefficient of correlation $r$ was $0 \cdot 702$.

The interpolation also was performed on each ear separately. The values obtained in the left ear were: $K_{O}=1.63$ $(\mathrm{t}=149 \cdot 83) ; \quad \mathrm{B}_{\mathrm{O}}=-0.0013(\mathrm{t}=7 \cdot 38) ; \mathrm{t}$ being the $t$ of Student, which indicates that the results are significant for both variables. The value of $r$ was $0 \cdot 67$, meaning that the $\log$ BTT behaviour can be explained as a function of age, with a probability of 59 per cent. For the right ear the results were: $\mathrm{K}_{\mathrm{O}}=1.63 \quad(\mathrm{t}=153.95) ; \quad \mathrm{B}_{\mathrm{O}}=-0.001$ $(\mathrm{t}=6.66) ; \mathrm{r}=0.73$. The $\log$ BTT-age correlation is explained with a probability of 54 per cent. The low scores of the correlation coefficients can be explained satisfactory if we consider the approximation due to the error in BTT measurement, the difficulty in peak identification and the individual variability in the from which one obtains the normalised regression equation:

(2) $\log$ BTT $=K_{0}+B_{O} T$

For the regression analysis, the method of least squares was used in a first step for all 133 BTT values. The result was:

$$
\begin{aligned}
& \text { BTT value at birth } \\
& \mathrm{B} \text { (slope of the curve) = matu- } \\
& \text { ration rate } \\
& \Gamma(\text { months })=\text { age }
\end{aligned}
$$

(1) $\log B T T=e^{K+B T} K(Y$ intercept $)=$ extrapolated 
years of age (Fig. 3). After that age, our experimental data confirmed that no significant shortening of the BTT takes place.

We were noi successful in finding a model which correlated the latency of wave I with age, which is not surprising considering the variability in middle-ear morphology, especially the development of mastoid pneumatisation, and the prevalence of minor middle-ear pathology in the children studied. Furthermore, when we attempted to clarify whether the interwave intervals which make up the BTT varied as a function of age, we found sufficient data only for measurements for the IV-III. An exponential function correlating the IV-III interval decrease with age was found, although the model was not identical to that for the BTT. However, this finding does not contradict the existence of a proportionally similar decrease between each two successive waves.

\section{Discussion}

This study has quantitatively described the rate at which BTT declines with age. It has been suggested that this is due to more rapid impulse propagation following the process of axonal myelination (Lieberman et al. 1973).

This data on normal values of BTT for age should contribute to the diagnosis of neurological disorders of neonates, infants and children. Patterns of the BTT decrease which deviate from normal may be indicative of some form of brainstem dysfunction. In addition, a deviant BTT recorded in an infant who had suffered a perinatal or congenital insult may serve as an early predictor of impending neurological or behavioral problems. Since BTT is defined as the time interval between wave $I$ and the positive peak following wave $v$ (or $4 b$ ) of the ABR trace, a measure of relative latency not influenced by the middle-ear apparatus is more meaningful than an absolute latency.

The progressive shortening of the BTT with age was also found in a longitudinal study of kittens by Shipley et al. (1980), which confirms the validity of the hypothesis proposed by Lieberman et al. (1973), that this phenomenon may be due to the physiological maturational process of the auditory pathway.

Establishing normal values for the BTT at successive maturational stages of the brainstem makes it possible to obtain information on several neuropathological conditions during infancy; in particular, those conditions due to structural defects or maturational retardation. From serial readings of the BTT, it is possible to ascertain normal growth of the brainstem structure of neonates and infants by means of the equations obtained in this study.

\footnotetext{
Authors' Appointments

- Mario Fabiani, Reparto di Fisiopatologia Uditiva, I Clinica Otorinolaringoiatrica dell'Università degli Studi di Roma 'La Sapienza', Roma.

Haim Sohmer, Department of Physiology, Hebrew University;Hadassab Medical School, Jerusalem, Israel.

Charles Tait, Speech and Hearing Sciences, University of Michigan, Ann Arbor.

Oreste Bordieri Facoltà di Statistica, Università degli Studi di Roma 'La Sapienza', Roma.

* Correspondence to first author: P.O. Box 168, Roma Centro, 00100 Roma.
}

\section{SUMMARY}

Brainstem transmission time (BTT) was studied in 71 subjects ranging in age from one day to 29 years in order to find a mathematical expression to best describe the relationship between BTT and age. The mathematical function which relates BTT to age is exponential. Using this data, the BTT confidence limit was calculated for subjects from birth through to cight years. Repeated recordings of auditory brainstem responses were performed in several children as they grew older and these verified the normal maturational processes of the brainstem structures in the developing infant and young child.

\section{RÉSUMÉ}

Expression mathèmalique entre le temps de transmission des stimuli auditifs dans le tronc cérébral el l'age Le temps de transmission du tronc cérébral (BTT) a été étudié chez 71 sujets âgés de un jour à 29 ans dans le but de trouver une expression mathématique pour décrire au mieux la relation entrc BTT et âge. La fonction mathématique qui relie le BIT ct l'âge est exponenticlle. En partant de cette donnćc, la limite de confiance du BTT a été calculée pour les sujets allant de la croissance à huit ans. Des enregistrements répétés de réponse auditive du tronc cérébral ont été réalisés chez plusieurs enfants devenus plus âgés et ils ont vérifié les processus de maturation normale des structures du tronc cérébral chez le nourrisson et le jeune enfant. 


\section{ZUSAMMENFASSUNG}

Eine mathematische Formel für die Beziehung zwischen akustischer Hirnstammtransmissionszeit und Aller Bei 71 Probanden im Alter von einem Tag bis zu 29 Jahren wurde die Hirnstammtransmissionszeit (HTZ) untersucht, um eine mathematische Formel zu finden, die die Beziehung zwischen HTZ und Alter am besten ausdrückt. Mathematisch handelt es sich bei der Beziehung zwischen HTZ und Alter um eine Exponentialfunktion. Unter Verwendung dieser Daten wurde die HTZ Vertrauensgrenze für Probanden von der Geburt bis zum achten Lebensjahr berechnet. Bei mehreren Kindern wurden in verschiedenen Alterstufen Aufzeichnungen akustischer Hirnstammreaktionen vorgenommen und dadurch die normalen Reifungsprozesse der Hirnstammstrukturen beim sich entwickelnden Säugling und Kleinkind verifiziert.

\section{RESUMEN}

Expressión matemática entre la relación de la edad y la edad y el tiempo de transmissión auditiva en el tronco cerebral Se estudió el tiempo de transmisión en el tronco cerebral (TTT) en 71 individuos cuyas edades oscilaban entre un dia y 29 años, con el objeto de hallar una expresión matemática que describiera lo mejor posible la relación entre la edad y el TTT. Uttilizando estos datos se calculó el límite de confianza del TTT en individuous desde el nacimiento hasta los ocho años. Se realizaron repetidas grabaciones de las respuestas auditivas en el tronco cerebral en diversos niños a medida que se hacian mayores, las cuales demonstraron los procesos normales de maduración de las estructuras del tronco cerebral en el lactante en fase de maduración y en el niño mayor.

\section{References}

Brama, I., Sohmer, H. (1977) Auditory nerve and brainstem responses to sound stimuli at various frequencies.' Audiology, 16, 402-408

Chiappa, K. H., Gladstone, K. J. (1978) 'The limits of normal variations in waves I and II of the human brainstem auditory response.' Neurology, 28, 402. (Abstract.)

Duncan, P. G., Sanders, R. A., McCullough, D. W. (1979) 'Preservation of auditory evoked brainstem responses in anesthetized children.' Canadian Anaesthetists Society Journal, 26, 492-495.

Fabiani, M., Sohmer, H., Tait, C., Gafni, M., Kinarti, R. (1979) 'A functional measure of brain activity: brain stem transmission time.' Electroencephalography and Clinical Neurophysiology, 47, 483-491.

Hecox, K., Galambos, R. (1974) 'Brainstem auditory evoked responses in human infants and adults.' Archives of Otolaryngology, 99, 30-33.

Hyde, M. L., Stephens, S. D. G., Thornton, A. R. D. (1976) 'Stimulus repetition rate and the early brainstem responses.' British Journal of Audiology. 10, 41-50.

Lieberman, A., Sohmer, H., Szabo, G. (1973) 'Standard values of amplitude and latency of cochlear audiometry (electro-cochleography) responses in different age groups.' Archiv für klinische und experimentale Ohren- Nasen- und KehlkopfHeilkunde, 203, 267-273.
Pratt, H., Sohmer, H. (1976) 'Intensity and rate functions of cochlear and brainstem evoked responses to click stimuli in man.'Archives of Oto-rhino-laryngology, 212, 85-93.

Salamy, A., McKean, C. M. (1976) 'Postnatal development of human brain stem potentials during the first year of life.' Electroencephalography and Clinical Neurophysiology, 40, 418-426.

- - Buda, F. B. (1975) 'Maturational changes in auditory transmission as reflected in human brain stem potentials.' Brain Research, 96, 361-366.

Shipley, C., Buchwald, J. S., Norman, R., Guthrie, D. (1980) 'Brain stem auditory evoked response development in the kitten.' Brain Research, 182, 313-326.

Sohmer, H., Cohen, D. (1976) 'Responses of the auditory pathway in several types of hearing loss.' In Ruben, R., Elberling, C., Salamon, G. (Eds.) Electrocochleography. Baltimore: University Park Press. pp. 431-437.

- Student, M. (1978) 'Auditory nerve and brain stem evoked responses in normal, autistic, minimal brain dysfunction and psychomotor retarded children.' Electroencephalography and Clinical Neurophysiology, 44, 380-388.

Starr, A. (1977) 'Clinical relevance of brain stem auditory evoked potentials in the brainstem in man.' In Desmedt, J. (Ed.) Auditory Evoked Potentials in Man. Basel: Karger. pp. 45-57. 